\section{FIGURE 3}

\section{RISK FACTORS IN MALE HEALTH}

1

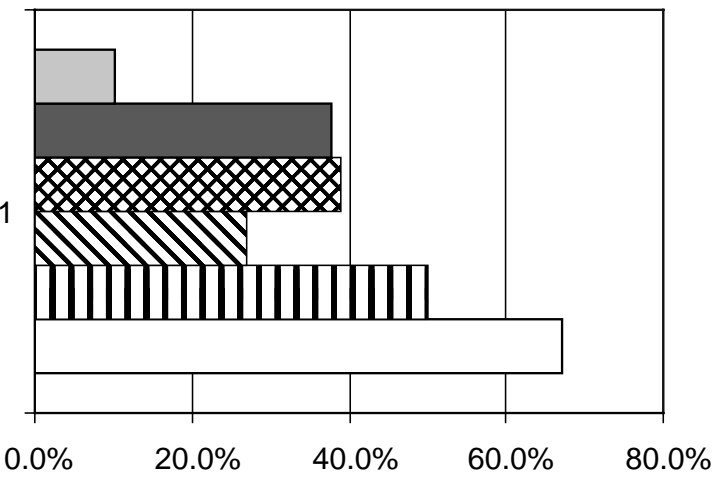

Key

$\square$ Eats required level of vegetables

$\square$ Eats Required level of fruits

$\square$ Application of sunscreen

$\Delta$ Smoking

I Overweight and obese

$\square$ Adequate physical activity

Source: 1997-1998 NSW Health Survey Report. ${ }^{2}$

tend to use health services at a lower rate than women, and die more frequently from cardiovascular disease, cancer, and injury including suicide. They also have poor health-related behaviours in health screening, nutrition, and smoking. Men also experience higher levels of hospitalisation due to work-related injuries.

As stated in Moving Forward in Men's Health, in order to promote and improve men's health, and make health services more appealling to men, further research is required into men's health, as well as a community-wide and intersectoral approach, so that all sectors of the community are working together.

\section{REFERENCES}

1. Public Health Division. The Health of the People of NSWReport of the Chief Health Officer 2000. Sydney: NSW Department of Health, 2000.

2. NSW Department of Health. 1997-1998 NSW Health Survey Report. www.health.nsw.gov.au.

3. World Health Organization. The World Health Report 2001Mental Health: New Understanding, New Hope. Geneva: World Health Organization, 2001.

4. AIHW. Australia's Health 2000. Canberra: AIHW, 2000.

5. Muscatello D, Mitchell R. Identifying Work-Related Injury and Disease in Routinely Collected NSW Hospitalisation Data. NSW Public Health Bulletin 2001; 12(7): 193-196.

6. Why Young Males. Australian Injury Prevention Bulletin. Issue $11,1995$.

7. Injury Patterns. Australian Injury Prevention Bulletin. Issue 11, 1995.

8. Ansari G, Chipps J, Stewart G. Suicide in New South Wales: The NSW Suicide Data Report. NSW Public Health Bulletin 2001; 12(3): 80-84.

9. AIHW. Australia's Health 1998. Canberra: AIHW, 1998.

10. Policy Division. Moving Forward in Men's Health. Sydney: NSW Department of Health, 1999.

11. Wilkinson RG and Marmot MG (editors). The Social Determinants of Health: the solid facts. Copenhagen: World Health Organization Centre for Urban Health, 1998.

12. Morrell SL, Taylor RJ, Kerr CB. Unemployment and Young People's Health. Med J Aust 1998; 168: 236-240.

13. Australian Bureau of Statistics. Year Book Australia - No. 83. Canberra: AusInfo, 2001.

14. Harris E, Harris M, Lee P, Powell Davies G. Taking Action to Address the Health Impact of Unemployment: Experiences from South Western Sydney. Sydney: CHETRE, 1999. 멸

\title{
THE WELLBEING OF BOYS
}

\section{Richard Fletcher}

Manager, Men and Boys Program,

Family Action Centre, University of Newcastle

This article describes the current health status of boys between $0-14$ years, and suggests ways that their wellbeing could be improved.

\section{HEALTH STATUS OF BOYS}

Boys in NSW have higher rates of death than girls in NSW for all major causes of childhood death (Figure 1). Boys also have higher rates of illness. For example, based on data presented in the Health of the People of NSW-Report of the Chief Health Officer 2000, ${ }^{1}$ boys have higher rates for hospital separations in NSW for respiratory diseases, perinatal conditions, and injury or poisoning. ${ }^{1}$ National health data shows that, when compared to girls, boys have higher rates of disability, handicap, and chronic and recent illness. ${ }^{2}$ Boys' wellbeing is also reflected in social indicators of health such as literacy levels, academic achievement and anti-social behaviour.

Nationally, for every socioeconomic group, boys perform worse than girls in assessments of literacy, and the gender gap is larger in the lower socioeconomic groups. ${ }^{3}$ Since 1975 , there is evidence of a decline in mastery of reading at age 14 among boys that is not evident among girls. ${ }^{4}$ When compared to girls, boys' achievement at university entrance level has also shown a recent decline in NSW, from 0.6 marks below girls in 1981 to 19.4 marks below girls in $1996 .{ }^{5}$ Eighty per cent of individuals suspended from school are boys, and boys are twice as likely as girls 
to be suspended for violent behaviour. ${ }^{6}$ Sex differences in school-aged behaviour are reflected in more serious illegal activity; for example, 10-14 year old boys are four times more likely than girls to appear before the children's and local courts in NSW. ${ }^{7}$

A clear mandate exists to target boys' health, with particular attention to boys within already recognised priority groups such as indigenous and low-income populations.

\section{IMPROVING THE WELLBEING OF BOYS}

To improve boys' wellbeing, interventions do not have to be focused exclusively on boys. For example, recent changes to asthma management benefit all children but have benefited boys in particular because of their higher rate of asthma. However, where behavioural change is required improvements will be more difficult to achieve. It is where boys' sense of expected male behaviour is involved that health services have the most difficulty in intervening.

At seminars on boy's and men's health across NSW, male and female health workers, educators and parents have expressed their uncertainty in the question: 'How do we get through to boys?' Boys' health-damaging behaviours, beliefs and attitudes are often clear enough. What is not clear is how to proceed. A lack of appropriate male role models for boys, in the family, in the community, and within health services, is commonly raised as a difficulty for promoting effective change. ${ }^{8}$
Boys' health is most appropriately addressed in the context of male health; consequently, the Moving Forward in Men's Health policy provides a suitable starting point. ${ }^{9}$ However, the gap between policy and service delivery remains wide, and some important issues in boys' wellbeing are not addressed. One example is male role modelling; when seeking male clinical staff or male mentors for boys, an agreed basis for selecting suitable male staff to become role models is required. Another example is male parenting; while fathers are regarded as essential for the development of children, the evidence base for deciding children's needs for paternal contact is lacking. Further, this gap in understanding of male parenting has consequences for all children but particularly for boys. The finding that boys in single parent families experience significantly worse health than girlsfor example: 28 per cent more chronic illnesses, 15 per cent more recent illnesses, 33 per cent more days of reduced activity - suggests that a stronger evidence base for male parenting is required. ${ }^{2}$

Research should underpin, and be linked to, general health initiatives to address boys' health and wellbeing. Opportunities to make immediate progress are provided through Families First and by school health services.

In recognition of the crucial role that parents play in developing healthy children and adults, ${ }^{10}$ the Families First initiative (see NSW Public Health Bulletin, Volume 11, Number 5) seeks to improve coordination and access to services, and to increase community support for families

\section{FIGURE 1}

DEATHS BY CATEGORY OF CAUSE AND SEX FOR PERSONS AGED 0 TO 14 YEARS, NSW 1995-98
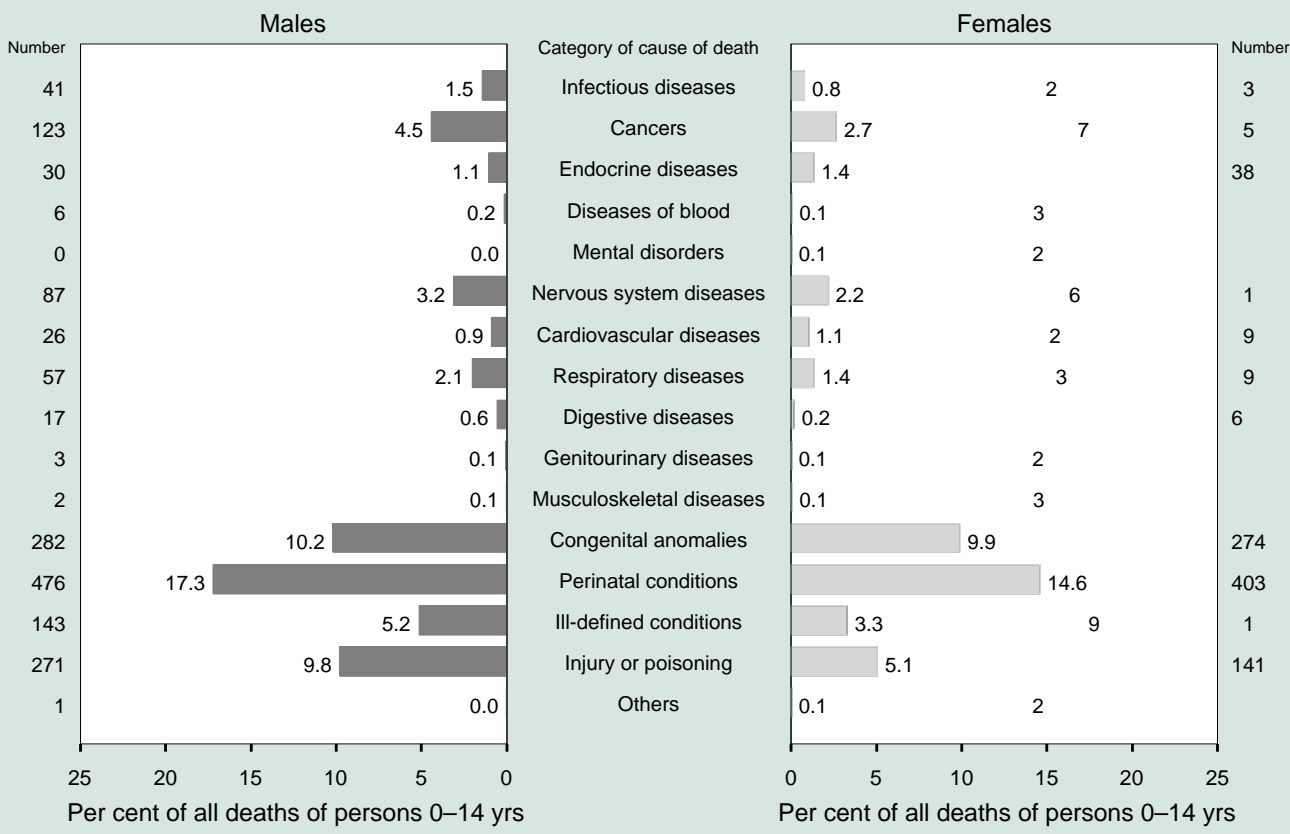

Source: The Health of the People of New South Wales-Report of the Chief Health Officer $2000 .{ }^{1}$ 
caring for infants and young children. However, the initiative has been gender-blind in that 'parent' is used when the clear reference is to 'mothers', and 'family' is used when in fact 'mothers and babies-infants-children' are the intended clients. For boys' wellbeing it is imperative to address the gender bias surrounding the planning and delivery of support to families. The settings for Families First have overwhelmingly female staff and clientele: antenatal, midwifery and early childhood services; and playgroups, pre-schools, day care centres and primary schools. In none of these services is male participation a measurable outcome. Most have no record of whether males attend or are involved. Many staff see no need to recruit or involve males. A British investigation into barriers to male use of family centres found that many services were 'agnostic' about male participation. ${ }^{11}$

A positive step is a current research project funded by the Hunter Valley Families First committee to investigate male access to family-related services. But leadership and resourcing across the state is required to make male participation in family-related services a legitimate target. If families are crucial to children's health, and if boys have demonstrably worse health, then it is essential to support both male and female parents.

Schools are recognised as important settings for healthy development. However, boys' wellbeing has not been a recognised outcome in either the primary or the secondary school systems, and so boys' needs have not been explicitly addressed. At the recent 4th National Men's and Boys' Health Conference, Professor Faith Trent shared her findings from the South Australian study of 1800 high school boys, most of whom reported experiencing a lack of respect for them in the school setting. ${ }^{12}$ Health services at state and regional level could advocate for attention to boys' wellbeing through linking health and welfare outcomes to those of schools.

The indicators outlined in the article 'Health of Children in South Western Sydney' (NSW Public Health Bulletin, Volume 9 Number 6-7) include school retention rate and juvenile justice, which provide a useful model. Additional indicators from the police and the Road Transport Authority - and more detailed information on literacy, school achievement, and suspensions - could provide indicators to inform planning and monitor progress. Health services could also support schools to develop 'holistic' approaches to boys' education - through changes to the curriculum and school structure-by addressing key health issues for boys such as: risk taking, social engagement, nutrition, and homophobia. ${ }^{13}$

In keeping with the commitment of the NSW Department of Health to have 'consumers' as active participants in health planning and service delivery, boys' involvement at every possible level would be an area for advocacy.

\section{CONCLUSION}

Community concern about boys' wellbeing is well founded. Addressing boys' health status will require continued improvements to areas of health service, promotion and prevention where boys are over represented in mortality and morbidity outcomes. As well, male gender issues will need to be included in the processes of health planning and service delivery. Traditionally femaleoriented family services could include males through policy development, resources, and through staff training. Health can also provide leadership in school health to coordinate and broaden the outcome measures used, to effectively address boys' health behaviours, and to advocate for boys' participation.

\section{REFERENCES}

1. Epidemiology and Surveillance Branch. The Health of the People of New South Wales-Report of the Chief Health Officer 2000. Sydney: NSW Department of Health Department, 2000. Available at:

www.health.nsw.gov.au/public-health/chorep/choindex.htm.

2 Mathers C. Health differentials among Australian children. Australian Institute of Health and Welfare: health monitoring series No. 3. Canberra: Australian Government Publishing Service, 1995; vi, vii.

3. Department of Education, Training and Youth Affairs. The Education of Boys. Submission to the House of Representatives Standing Committee on Employment, Education and Workplace Relations, 2000.

www.aph.gov.au/house/committee/eewr/eofb.

4. Marks G N, Ainley J. Reading Comprehension and Numeracy among Junior Secondary School Students in Australia. Longitudinal Survey of Australian Youth Research Report No 3. Melbourne: ACER, 1997.

5. MacCann R. A Longitudinal Study of Sex Differences at the Higher School Certificate and School Certificate: Trends over the Last Decade. Sydney: NSW Board of Studies, 1995.

6. Raethel S. 26 Jul 1996. Sydney Morning Herald, News and Features Section, page 2-3.

7. NSW Attorney General's Department. Juvenile Crime in New South Wales Report: A Review of Literature 1997. Sydney: NSW Attorney General' Department, 1997.

8. Fletcher R. Documentation report: The Men and Boys Project of the Family Action Centre The University of Newcastle. Callaghan: The University of Newcastle, 1999.

9. Policy Division. Moving Forward in Men's Health Sydney: NSW Department of Health, 1999.

10. Nossar V, Alperstein G. Key initiatives to achieve health gain for children. NSW Public Health Bulletin 1998; 9(11): 126127.

11. Ghate D, Shaw C, Hazel N. Fathers and family centres: engaging fathers in preventive services. London: Joseph Rowntree Foundation, 2000.

12. Trent F. What the Boys' are Saying. Proceedings of the 4th National Men's and Boys' Health Conference, Richmond NSW, 27-29 September 2001 (unpublished).

13. Fletcher R. A whole-school approach to boys' education. Classroom 2000; 6: 12-14. 喿 